\title{
Produkty z kryla antarktycznego Euphausia superba-zdrowie na talerzu czy zdrowy ekosystem?
}

\author{
Kinga Hoszek \\ Uniwersytet Gdański \\ Wydziat Oceanografii i Geografii, Instytut Oceanografii \\ E-mail: nanohoszek@gmail.com \\ tutor: dr Anna Panasiuk \\ Uniwersytet Gdański \\ Wydział Oceanografii i Geografii, Instytut Oceanografii, Zakład Badań Planktonu Morskiego
}

Stowa kluczowe: Antarktyka, polowy komercyjne, kryl antarktyczny, akwakultury

\section{Wstęp}

Kryl antarktyczny (Euphasia superba) jest małym skorupiakiem, podobnym do krewetki. Jest gatunkiem żerujących na fitoplanktonie i głównym źródłem pokarmu dla wielu antarktycznych drapieżników, takich jak wieloryby, pingwiny, foki przez co odgrywa kluczową rolę $w$ sieci troficznej tego ekosystemu (Santa Cruz i in., 2018). Dodatkowo, dzięki swojej dużej biomasie i codziennym migracjom pionowym transportuje i przekształca niezbędne składniki odżywcze, stymulując produkcję pierwotną i pochłaniając dwutlenek węgla (Cavan i in., 2019).

Gatunek ten jest poławiany między innymi z powodu zasobności w proteiny, wielonienasycone kwasy tłuszczowe, minerały, duże ilości witamin A i E oraz barwników ksantofilowych (Zhang, 2019). Połowy kryla rozpoczęto $w$ połowie lat sześćdziesiątych
XX wieku. Początkowo ich poziom był niski, lecz około 1973 roku przybrały bardziej komercyjny charakter, a ich ilość wzrosła. Produkty z kryla zaczęły być używane jako dodatki do pasz (głównie w akwakulturze), ale także jako składnik suplementów diety i kosmetyków (Nicol i Endo, 1999). Aby zapobiec nadmiernej eksploatacji tego niezwykle ważnego gatunku, w 1980 roku została założona Komisja ds. Ochrony Morskich Zasobów Żywych Antarktyki (Commission for the Conservation of Antarctic Marine Living Resources - C(AMLR) [1]. Jej celem jest ochrona morskiej fauny i flory Antarktydy, poprzez prowadzenie badań środowiskowych oraz monitorowanie połowów kryla (Arana i in., 2020). Komisja ta rekomenduje limity połowów tego gatunku, mając na uwadze jego wpływ na cały ekosystem, uwzględnia także warunki zewnętrzne wpływające na populacje tego skorupiaka, takie jak zmiany klimatu [1]. Mimo działań CCAMLR coroczny wzrost zapotrzebowania na produkty z kryla 


\section{Tutoring Gedanensis}

oraz szybko postępujące zmiany klimatu niepokoją naukowców (Piñones i Fedorov, 2016).

Kryl antarktyczny - elementy biologii i ekologii

W wodach Antarktyki dotychczas rozpoznano siedem gatunków kryla: Euphausia superba, Euphausia crystallo-rophias, Euphausia frigida, Euphausia longirostris, Euphausia triacantha, Euphausia valentini $i$ Thysanoessa macrura. Wśród nich dominuje Euphausia superba - kryl antarktyczny (Ryc. 1) (Mcbride i in., 2014). Słowo "kryl" było używane jako pierwsze przez norweskich wielorybników, jako określenie rojących się małych rybek, sygnalizujących bliskość żerowiska wielorybów (Arana i in., 2020). Ommaney w swojej pracy z 1938 roku opisał kryl antarktyczny jako "Stworzenie o delikatnej i pierzastej urodzie, czerwonawo-brązowe iszklisto transparentne. Pływa ono z osobliwą celowością, charakterystyczną dla krewetek. Wszystkie czułki ma wyczulone na dotyk, niesamowicie wrażliwe, a jego wystające, czarne oczy skierowane są do przodu jak lampy. Porusza się powoli, jakby z określonym celem, pracując w rytmie pierzastymi kończynami i za dotknięciem swoich czułków strzela do tyłu z niezwykłą szybkością, aby ponownie rozpocząć ostrożny postęp". Jest jednym z najlepiej zbadanych gatunków zwierząt pelagicznych, jednak nadal istnieją poważne wątpliwości co do kluczowych elementów jego biologii oraz procesów, które determinują jego rozmieszczenie i liczebność (Nicol, 2006).

Kryl antarktyczny zasiedla Ocean Południowy głównie na południe od frontu polarnego (Ryc. 2). Jego dystrybucja koncentruje się w obszarach letnich zakwitów fitoplanktonu oraz rozległego, zimowego lodu zapewniającego obfite pożywienie w postaci glonów lodowych (Atkinson i in., 2004).

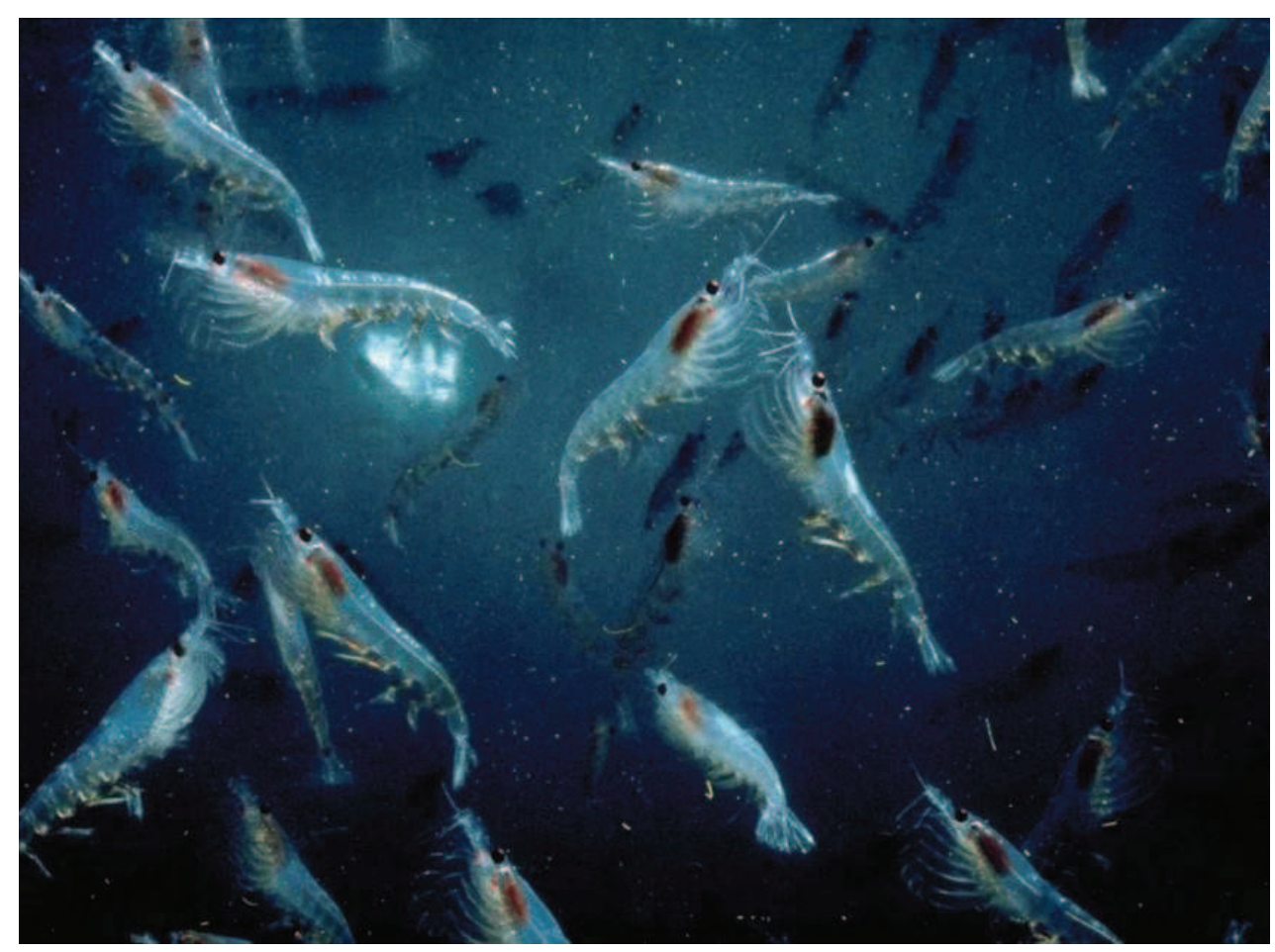

Ryc. 1. Kryl antarktyczny [1] 


\section{Tutoring Gedanensis}

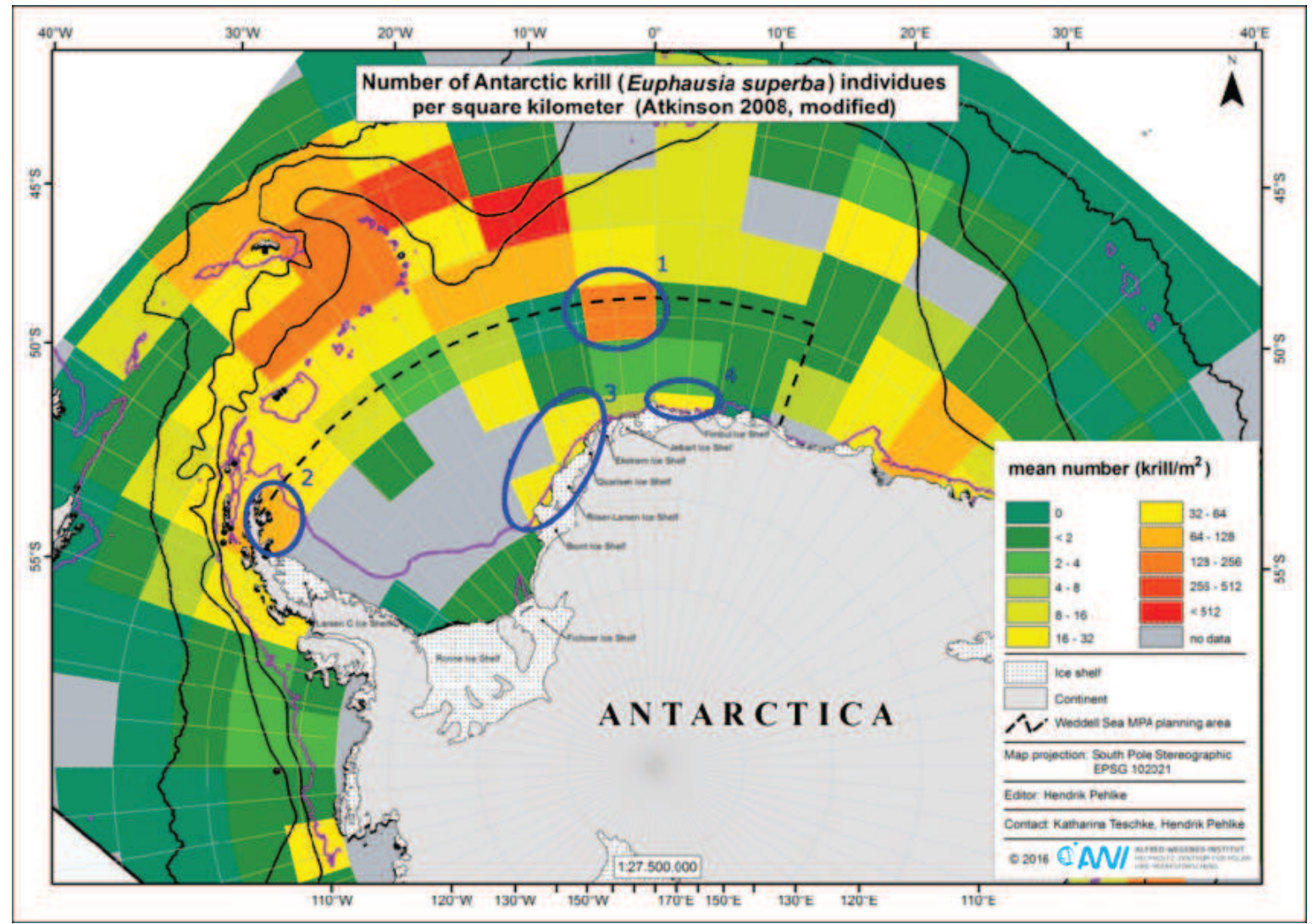

Ryc. 2. Rozmieszczenie kryla antarktycznego (Euphausia superba), (Teschke i in., 2016)

Kryl antarktyczny gromadzi się w ogromnych skupiskach liczących miliony osobników, ważących setki, a nawet tysiące ton i pokrywających duże obszary. Te gęste "roje" można spotkać od powierzchni morza do głębokości 600 metrów. Kryl wykazuje masowe codzienne migracje pionowe, dzięki czemu znaczna ilość jego biomasy jest dostępna jako pokarm dla drapieżników w pobliżu powierzchni w nocy oraz w głębszych wodach w ciągu dnia. Na rozkład populacji kryla mogą wpływać prądy, ukształtowanie dna, rozmieszczenie pokarmu i obecność drapieżników (Arana i in., 2020). Euphausia superba jest kluczowym gatunkiem w morskiej sieci pokarmowej Antarktyki (Ryc. 3), odgrywającym fundamentalną rolę w przekazywaniu energii między niższym, a najwyższym poziomem troficznym (Piñones i Fedorov, 2016).

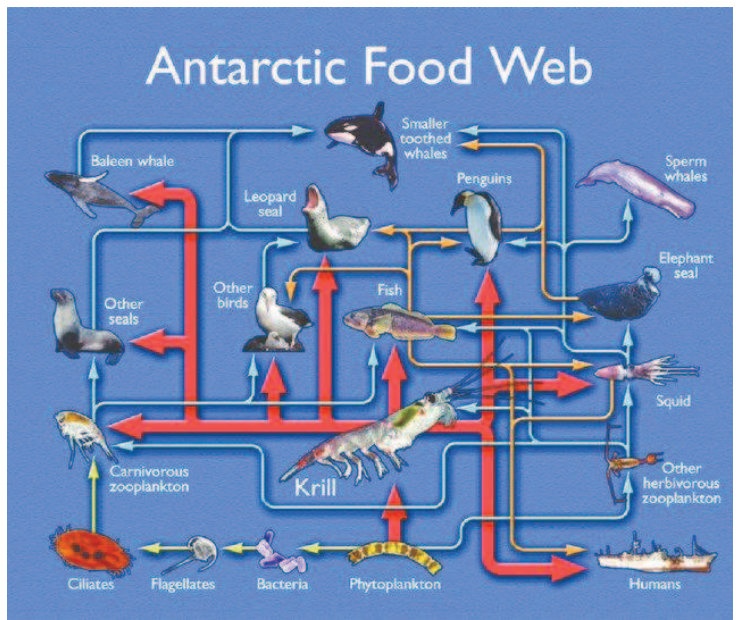

Ryc. 3. Sieć pokarmowa Antarktyki,

(Drinkwater i in., 2014)

Wiele gatunków morskich znajdujących się na wyższym poziomie troficznym w Oceanie Południowym żywi się krylem - są to ryby, wieloryby, foki, pingwiny, albatrosy, petrele i kałamarnice. Uzależnienie wielu drapieżników oraz producentów od jednego 
gatunku poskutkowało powstaniem tak zwanego "ekosystemu o talii osy", charakteryzującego się zdominowaniem średniego poziomu troficznego przez tylko jeden gatunek. Dlatego też wszelkie zaburzenia w populacji kryla mają poważne konsekwencje w całym ekosystemie Oceanu Południowego (Atkinson i in., 2004; Drinkwater i in., 2014). Niektórzy naukowcy przypisują krylowi jeszcze większe atuty. Uważają, że kryl odgrywa ważną rolę w "kontroli" klimatu. Żerując na fitoplanktonie, który pochłania $\mathrm{CO}_{2}$ nagromadzony na powierzchni wody, kryl przekształca i transportuje niezbędne składniki odżywcze tysiące metrów pod powierzchnię wody i wydala je w postaci odchodów, wpływając na tak zwaną pompę biologiczną (Cavan i in.,2019, [2]).

Stabilność populacji kryla jest narażona na wiele zagrożeń, nie tylko ze strony odżywiających się nim drapieżników. Życie nowego pokolenia kryla zaczyna się latem, kiedy samice składają jaja w górnym słupie wody oceanu (Ryc. 4) Uwolnione embriony opadają w miarę rozwoju, a na głębokości 700-1000 m wykluwają się larwy. Wznoszą się one ku powierzchni i już jako młode osobniki czekają na nadejście następnego lata. W swoim wczesnym okresie życia przechodzą trzy krytyczne momenty mające największy wpływ na ich przeżycie. Pierwszy okres następuje w trakcie rozwoju larw do pierwszego etapu żerowania po zakończeniu cyklu opadania-wynurzania. Na powierzchni wody larwy kryla mają tylko około 10 dni na znalezienie pożywienia przed osiągnięciem tak zwanego progu głodu, po którym larwy nie przeżywają, nawet jeśli pożywienie nagle stanie się dostępne. Drugi krytyczny okres przypada późnym latem i jesienią, kiedy dostępność pokarmu pozwala larwom zgromadzić wystarczające rezerwy lipidów. Trzeci krytyczny okres przypada na pierwszą zimę, kiedy stają się źródłem pożywienia dla innych gatunków morskich, podczas którego używają lodu morskiego jako schronienia (Nicol 2006; Piñones i Fedorov, 2016). Aby sprostać swojemu zapotrzebowaniu metabolicznemu i dorosnąć, larwy kryla muszą żerować zimą (Nicol 2006; Piñones i Fedorov, 2016). Dlatego warunki środowiskowe, takie jak temperatura oceanu i zasięg lodu morskiego, mają dominujący wpływ na przetrwanie larw. Temperatura wpływa na cykl opadania i wznoszenia, a lód morski wpływa

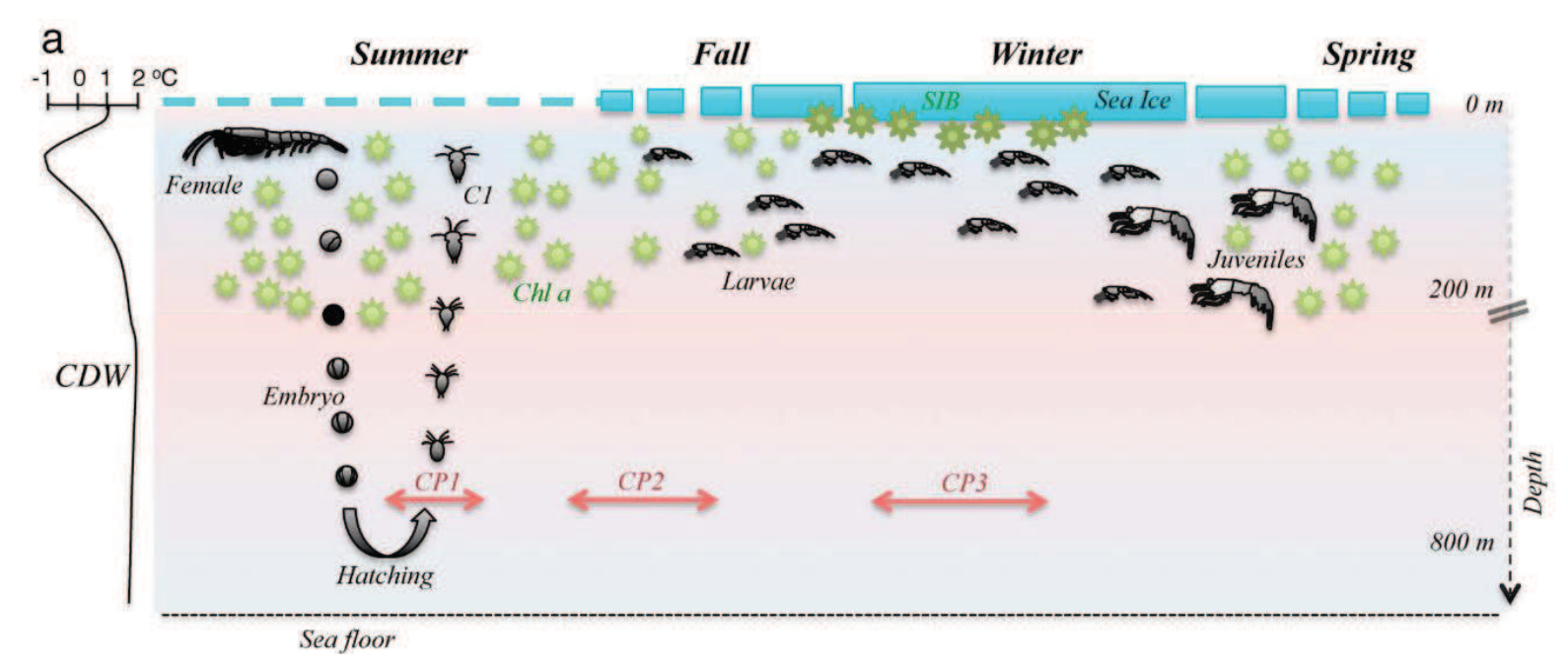

Ryc. 4. Cykl życia kryla antarktycznego, (Piñones i Fedorov, 2016) 
na dostępność pożywienia i schronienia w okresie zimowym. Zmiana warunków środowiskowych obszarów antarktycznych między innymi w skutek globalnego ocieplenia, a w konsekwencji cofanie się zimowego lodu morskiego może stać się dominującym czynnikiem powodującym spadek populacji kryla. Rosnąca temperatura wód powoduje szybszy rozwój larw, jednakże jednocześnie jest czynnikiem stresowym zarówno dla nich, jak i osobników dorosłych, wypływającym na ich metabolizm i procesy fizjologiczne.

Zmniejszenie się o 80\% siedlisk dostępnych do tarła kryla także budzi poważne obawy (Piñones i Fedorov, 2016). Problemem jest też zakwaszanie oceanów, negatywnie wpływające na jaja kryla (Nicol i Endo, 1999; Kawaguchi i in., 2013). Łączny skutek zachodzących zmian jest trudny do przewidzenia, ale już pojawiły się oznaki, że spowodowały duże zmiany w rozmieszczeniu ławic kryla i ich liczebności, mimo, iż według statystyk nie są nadmiernie eksploatowane. Jakiekolwiek, dalsze zakłócenie siedliska kryla będzie miało poważne konsekwencje dla ekosystemów Antarktyki (Atkinson i in, 2008; Piñones i Fedorov, 2016).

Znaczenie ekonomiczne kryla antarktycznego Euphausia superba

W ciągu ostatnich pięciu dekad kryl był celem rosnącego popytu w rybołówstwie komercyjnym (Ichii, 2000). Ludzie wykorzystują białko kryla oraz jego produkty uboczne. Jest on substratem do wytwarzania past z kryla przeznaczonych do spożycia przez ludzi, hydrolizatów - mączek z kryla służących do zbilansowania paszy dla zwierząt, dodatków jako pasza w akwakulturze, a także produktów pochodnych, takich jak tabletki omega3, barwniki, oleje z kryla używanych w nutriceutyce, kosmetyce i farmaceutyce. Dużo takich produktów zostało już opatentowanych - aż 376 (dane z 2003 roku). Większość pa- tentów jest w posiadaniu firm oraz osób prywatnych z Japonii, która ma najdłuższą historię w połowach kryla (Nicol i Endo, 1999; Nicol, Foster, 2003; Arana i in, 2020).

Około dwadzieścia lat temu połowy kryla antarktycznego były ograniczane przez czynniki ekonomiczne i marketingowe związane z wysokimi kosztami i problemami w przetwarzaniu oraz brakiem popytu. Większość kryla złowionego w rybołówstwie komercyjnym była wykorzystywana w paszach dla akwakultury jako źródło pigmentu białkowego i miąższowego (Hewitt Linen Low, 2000). Jednakże od tamtego czasu wiele się zmieniło, zwiększyła się populacja ludzka, jej zapotrzebowanie na źródła pożywienia. Odkryto przydatność kryla w innych, wymienionych wcześniej, gałęziach przemysłu. Pokonano także niektóre ograniczenia techniczne (Nicol i Endo, 1999). Skorupiaki te mają bardzo delikatny szkielet zewnętrzny, którą łatwo ulega uszkodzeniom jeśli osobnik zapląta się w siatkę. Po zmiażdżeniu enzymy uwięzione $w$ jego układzie pokarmowym rozkładają miąższ tak szybko, że produkt momentalnie staje się bezwartościowy. Techniczna ewolucja zamiany tradycyjnej siatki połowowej na system ciągłego pompowania zaprojektowaną przez norweskich inżynierów rozwiązała ten problem. Jest to narzędzie zwiększające zyski. Wielkość połowów przy tradycyjnych metodach wynosiła ok.100 ton kryla na dzień, pompa jest w stanie w tym samym czasie pobrać 800 ton, ale uniemożliwia jednocześnie ważenie kryla, pracuje ciągle, bez przerwy i pozostawia bardzo duży margines błędu w obliczaniu wielkości połowu, a co za tym idzie statki nie są w stanie dokładnie raportować, w jakiej dokładnej ilości dana jednostka pozyskuje kryl (Nicol i Endo, 1999, [3, 4]). Zainwestowano także w chwytliwy marketing. Aker BioMarine, jedna z największych norweskich firm zajmujących się produkcją produktów z kryla, w swoich reklamach zapewnia o wol- 
ności ich produktów od zanieczyszczeń, takich jak na przykład metale ciężkie czy pestycydy dzięki łowieniu organizmów pochodzących z najbardziej dziewiczego oceanu świata [4], co zwiększa popyt na ich produkty. Przedstawia swoje działania jako zrównoważone i nie mające najmniejszego wpływu na środowisko, co nie raz spotkało się z krytyką NGO, wskazujących zagrożenie jakim są komercyjne połowy kryla [3]. Krytykowany jest także proces pozyskiwania przez te firmy certyfikatów MSC, który został przyznany firmie Aker BioMarine Antarctic Krill pomimo negatywnego wpływu połowów na organizmy zależne od krylu (Christian i in., 2013).

Kryl antarktyczny jako składnik paszy w akwakulturach

Kryl był używany w akwakulturze od dziesięcioleci. Mączki z kryla zawierają kluczowe składniki odżywcze, w tym aminokwasy, długołańcuchowe kwasy tłuszczowe, fosfolipidy, cholesterol, astaksantynę i cholinę (Nicol i Endo,1999; [5]; [6], [7], [8]). Jest jednym z najskuteczniejszych obecnie dostępnych środków poprawiających smak ryb hodowlanych. Wykazano, że już przy małych ilościach przyspiesza wzrost ryb oraz poprawia kolor i smak łososi i krewetek. Nie jest jednakże używany jako główny składnik pasz, a jedynie jako dodatek do pasz rybnych ([9], Storebakken, 1988). Z roku na rok popyt na kryl i produkty z niego pozyskiwane rośnie, w roku 2020 roczny połów wyniósł ponad 450000 ton (Ryc. 5) [3]. Kryl jest częścią naturalnej diety wielu ryb, takich jak łosoś w oceanach. Mączki z niego produkowane są uważane za swoisty "pakiet” składników odżywczych: witamin, astaksantyny, minerałów, który wpływa na poprawę parametrów zdrowotnych oraz ich lepszy wzrost, a co za tym idzie zdrowsze mięso dostępne jako pożywienie dla człowieka [10].

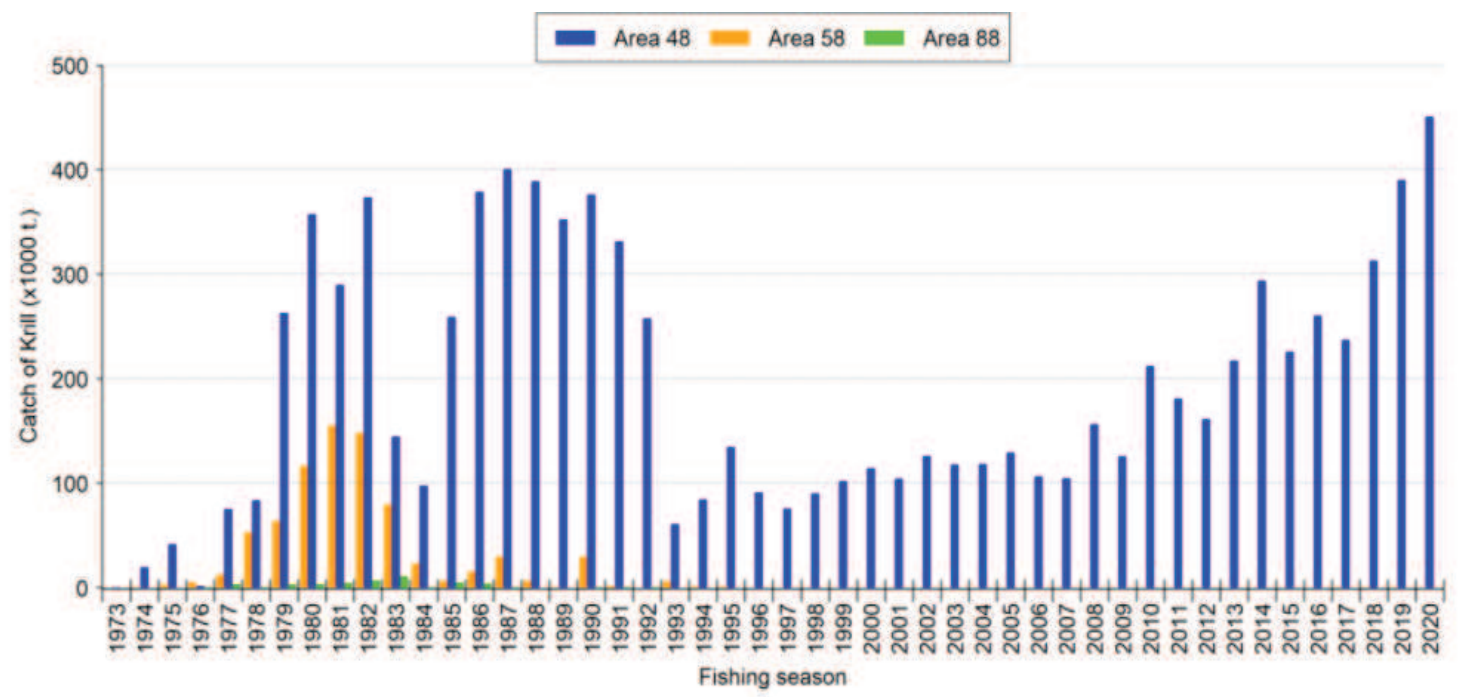

Ryc. 5. Roczne połowy kryla antarktycznego (Euphausia superba) na obszarze objętym konwencją CCAMLR [3]

Kryl antarktyczny jest promowany jako zdrowy pokarm bez wad. I faktycznie, jest on bogaty w dużo bardziej biodostępne składniki odżywcze, niż te pozyskiwane na przykład z ryb (Zhang i in., 2019, Ulven, Holven, 2015, Nash i in., 2014), jednakże zawiera on w swoich tkankach bardzo duże ilości fluoru (nawet do $4260 \mathrm{mg} / \mathrm{kg}$ suchej masy 


\section{Tutoring Gedanensis}

w karapaksie oraz 570 mg/kg suchej masy w mięśniach) (Soevik i Braekkan, 1979). Mimo, iż WHO nie zaakceptowała kryla jako możliwego do spożycia przez ludzi właśnie z powodu fluoru, którego dawka u dorosłych nie może przekraczać 2-4 mg dziennie, a u dzieci 1-2 mg dziennie, mączki z kryla są dozwolone do użytku jako pasza dla zwierząt (Zhang i in., 2019). Zhang i in. (2019) odkryli, iż u myszy karmionych mączką z kryla nie ma widocznych na pierwszy rzut oka zmian spowodowanych dużą ilością fluoru, a jednak badanie histopatologiczne wykazało, iż jest on akumulowany w kościach, wątrobie i nerkach (Ryc. 7), prowadząc do ich zniszczenia. Wykazano także, iż kryl nie jest wolny od zanieczyszczeń - jedynie mieści się on w ramach średnich wartości, odzwierciedlając profil chemiczny środowiska (Nash i in., 2014).
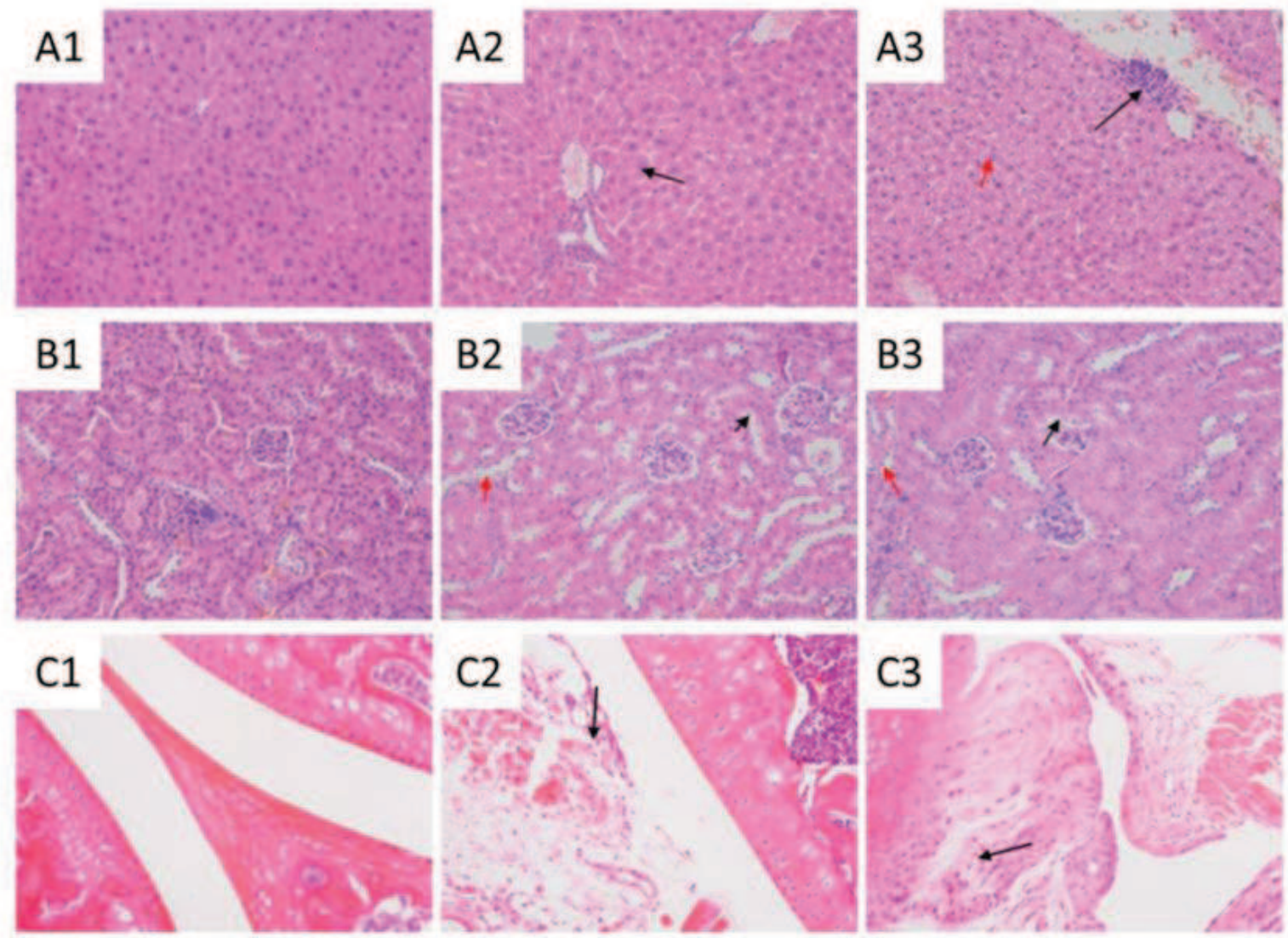

Ryc. 7. Mikrofotografia skrawków wątroby (A), wycinku nerki (B), skrawku kości (C) myszy z grypy kontrolnej (1), grupy karmionej krylem (2), grupy karmionej fluorkiem sodu (3) (Zhang i in., 2019)

\section{Kryl antarktyczny jako suplement diety}

Jednym z topowych aktualnie produktów jest olej z kryla, reklamowany jako źródło kwasów omega 3 DHA/EPA i choliny, które chronią przed otyłością, chorobami krążenia, nowotworami, chorobami neurologicznymi i wspomagają układ odpornościowy organizmu oraz astaksantyny, która jest anty-oksydantem pomagającym przeciwdziałać stresowi oksydacyjnemu, a co za tym idzie nowotworom, chorobom układu krążenia, cukrzycy, chorobie Parkinsona, Alzheimera i niektórym chorobom oczu ([7], [8]). Jednakże wyniki badań mające potwierdzić lub wykluczyć prozdrowotne działanie oleju 
z kryla są bardzo niespójne i wzajemnie się wykluczające. Okazuje się, iż nie ma wystarczających dowodów na działanie oleju z kryla na większość wymienionych wyżej problemów zdrowotnych, nie ma istotnych korzyści sercowo - naczyniowych oraz nie ma wpływu na zdolności poznawcze podczas suplementacji olejem z krylu u zdrowych dorosłych, a korzyści przy suplementacji olejem z kryla zostały zaobserwowane tylko w określonych przypadkach ([9], Prado-Cabrelo i Nolan, 2021). Istnieją oczywiście grupy społeczne, które mogą czerpać korzyści z oleju z kryla: wcześniaki, dzieci zagrożone chorobą psychiczną w dorosłym wieku z powodu genetycznie niskiego poziomu EPA i DHA oraz dla pacjentów z chorobą Alzheimera. Jednakże to tylko mała część populacji, której zaopatrzenie w olej wspomagający ich terapię jest istotne, a co za tym idzie, masowa produkcja na szeroką skalę i reklamowanie go jako suplement skierowany do zdrowych dorosłych jest zbędną eksploracją środowiska naturalnego, napędzaną jedynie czynnikami ekonomicznymi, a nie troską o zdrowie populacji (Prado-Cabrelo i Nolan, 2021).

\section{Zagrożenia}

Przez obawy, iż zwiększające się połowy kryla mogą mieć duży wpływa na ekosystem Oceanu Południowego, w 1980 zostało założona Komisja ds. Ochrony Morskich Zasobów Żywych Antarktyki (CCAMLR). Od tego czasu łowieniem kryla zarządza się bardzo ostrożnie. Wynika to z uznania krytycznej roli kryla w ekosystemie Antarktyki jako gatunku kluczowego oraz niepewności związanej ze zmianami środowiskowymi. Aktualnie, kryl antarktyczny (Euphausia superba) można poławiać na Oceanie Południowym w podobszarach 48.1-48.4, podobszarze 48.6 oraz rejonach 58.4.1 i 58.4.2 (Ryc. 6). Zrównoważony charakter połowów kryla jest zapewniony poprzez ustanowienie takich limitów poło- wów, aby połowy dokonywane przez te łowiska pozostawiły wystarczającą ilość kryla pozwalającą zapewnić zdrowe populacje drapieżników (takich jak pingwiny i wieloryby). Całkowity dopuszczalny połów w rejonie południowo-zachodniego Atlantyku wynosi obecnie około 5,6 miliona ton rocznie. CCAMLR rekomenduje, że połowy powinny być ograniczane w ramach poziomu "progu" wynoszącego 620000 ton, który jest rozłożony na cztery regiony południowo-zachodniego Atlantyku. Ten "poziom progowy” stanowi około $1 \%$ z szacowanych 60 milionów ton niewykorzystanej biomasy lub dziewiczej wielkości populacji kryla w tych obszarach (Kawaguchi i in. 2009, Cavanagh i in., 2016, [1]).

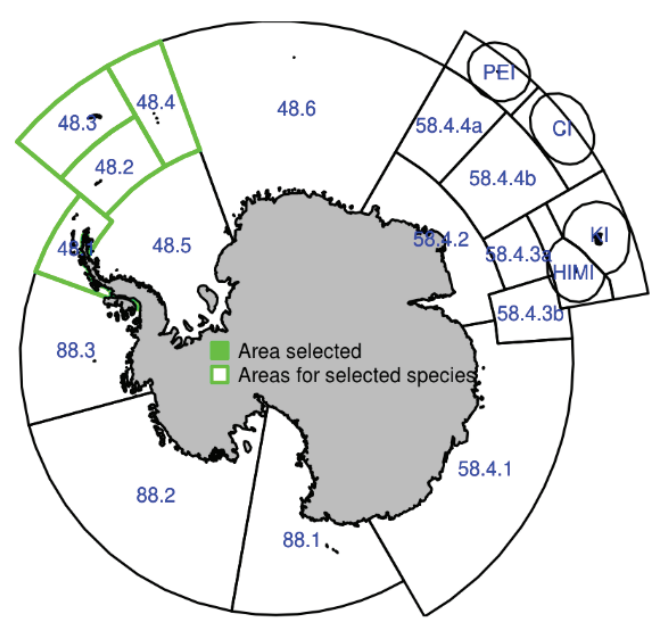

Ryc. 7. Mapa obszarów zarządzania na obszarze objętym konwencją CAMLR. Podobszary od 48.1 do 48.4 są zacieniowane na zielono; [3]

Mimo starań i pracy wykonywanej przez CAMLR, połowy kryla nadal stanowią zagrożenie dla ekosystemu Antarktyki. Wielkość rocznych połowów w ostatnich latach bardzo istotnie wzrosła (Ryc. 5), a ustalony limit połowów nadal stanowi zagrożenie dla ekosystemu (Medley i in., 2009; [3]). Jednakże problem nie dotyczy tylko ilości, ponieważ aktualne połowy nadal są daleko od progu wynoszącego 620000 ton, ale bardziej geograficznej koncentracji połowów, 
która może prowadzić do tak zwanego "lokalnego zubożenia" kryla. Łodzie rybackie koncentrują swoje działania na obszarach, które zapewniają schronienie przed warunkami pogodowymi, wzdłuż wybrzeża i między wyspami. Te obszary, na których działają statki rybackie, pokrywają się z obszarami żerowania drapieżników lądowych, takich jak foki i pingwiny, a także z miejscami żerowisk wielorybów. Człowiek i zwierzęta konkurują zatem bezpośrednio o ten sam kryl ([3]; Herr i in., 2016; Miller i in., 2010). Zwłaszcza pingwiny nie mogą przemieszczać się zbyt daleko od swoich gniazd w poszukiwaniu pożywienia podczas wychowywania piskląt (Miller i in., 2010). Krüger i in. w swoich badaniach z 2020 roku wykazali, iż szybkie zmiany klimatyczne na zachodnim Półwyspie Antarktycznym zmniejszają zagęszczenie kryla, który wraz z upływem czasu przy zwiększonej działalności połowowej w ostatnich dziesięcioleciach, ma synergistyczny wpływ na populacje gniazdujących w tym obszarze pingwinów. Zwiększenie połowów w okresie poza lęgowym wpływa na populacje zarówno na przedstawicieli Pygoscelis antarcticus, jak i Pygoscelis papua. Krüger i in. (2020) twierdzą, iż obecne zarządzanie połowami kryla na Oceanie Południowym uwzględnia arbitralne i ustalone limity połowowe, które nie odzwierciedlają zmienności populacji kryla pod wpływem zmian klimatycznych, a zatem wpływają na populacje pingwinów podczas niesprzyjających warunków środowiskowych. Aktualne zarządzanie połowami kryla zagraża także innym gatunków ptaków i ssaków zależnych od populacji kryla, szczególnie w letnich miesiącach, przez zakłócanie ich kolonii lęgowych (Hewitt, Linen Low, 2000; Hinke i in., 2017), a naukowcy dowodzą, iż populacja kryla stale się zmniejsza (Hill i in., 2019). Obecna forma modelu odłowu kryla nie odnosi się konkretnie do interakcji między połowami a żerowaniem drapieżników. Dodatkowo, populacja kryla jest wrażliwa na zmiany środowiskowe i klimatyczne, których nie jest się w stanie przewidzieć, a nawet jeden rok narażenia na gorsze warunki może spowodować istotne zmiany (Hewitt, Linen Low, 2000). Dodatkowo, kryl jest określany jako "białe złoto” i jego połowy są opłacalne, co ma odzwierciedlenie na przykład w sprzeciwie niektórych państw członkowskich CCAMLR na zmniejszenie limitów połowów podczas co rocznych spotkań SC-CCAMLR oraz trudnościach w utworzeniu morskich terenów chronionych, dzięki którym zwierzęta miałyby swoje ostoje, ale zagraża to interesom ekonomicznym (Brooks 2013).

\section{Podsumowanie}

Podsumowując, "na barkach" tego niewielkiego skorupiaka ciąży stabilność całego ekosystemu Antarktyki. Bez kryla wyginie wiele gatunków ryb, fok, pingwinów, wielorybów i innych antarktycznych zwierząt, dla których jest głównym, niemożliwym do zastąpienia źródłem pokarmu. Jest to ponadto gatunek niezwykle wrażliwy na zmiany klimatu.

Nie jest on niezbędnym składnikiem paszy w akwakulturze, okazuje się mieć neutralny wpływ na zdrowie dla większości ludzi, jest możliwy do zastąpienia np. ekstrakcję oleju z alg a dodatkowo okazuje się nie być tak nieskazitelnie "czysty” jak jest to reklamowane (problem z wysoką zawartością fluoru). Połowy oczywiście przynoszą korzyści ekonomiczne, lecz wydają się być one zdecydowanie bardziej dyktowane pobudkami właśnie ekonomicznymi niż humanitarnymi. Trzeba odpowiedzieć sobie na pytanie, czy na pewno możemy sobie pozwolić na zapłacenie tak wysokiej ceny za produkt, który w większości przypadków jest nam zbędny i czy nie lepiej skupić się na rozwinięciu gałęzi przemysłu spełniających podobną rolę, a jednocześnie nie prowadzących do utraty 
tak pięknego i dziewiczego ekosystemu, którym jest Antarktyka.

\section{Literatura:}

Arana, P. M., Rolleri, R., De Caso, Á., 2020. Chilean antarctic krill fishery (2011-2016). Latin American Journal of Aquatic Research, 48(2), 179-196.

Atkinson, A., 2008. Oceanic circumpolar habitats of Antarctic krill, Mar. Ecol. Prog. Ser., 362,1-23.

Atkinson, A., Siegel, V., Pakhomov, E., Rothery, P., 2004. Long-term decline in krill stock and increase in salps within the Southern Ocean. Nature, 432(7013), 100-103.

Atkinson, A., Siegel, V., Pakhomov, E., Rothery, P.,2004. Long-term decline in krill stock and increase in salps within the Southern Ocean. Nature, 432(7013), 100-103.

Brooks, C.M., 2013. Competing values on the Antarctic high seas: CCAMLR and the challenge of marine-protected areas. The Polar Journal 3: 277-300

Cavan, E. L., Belcher, A., Atkinson, A., Hill, S. L., Kawaguchi, S., McCormack, S., Meyer, B., Nicol, S., Ratnarajah, L., Schmidt, K., Steinberg, D. K., Tarling, G. A., Boyd, P. W., 2019. The importance of Antarctic krill in biogeochemical cycles. Nature Communications, 10(1), 1-13.

Cavanagh, R. D., Hill, S. L., Knowland, C. A., Grant, S. M., 2016. Stakeholder perspectives on ecosystem-based management of the Antarctic krill fishery. Marine Policy, 68, 205-211. https://doi.org/10.1016/j.marpol.2016.03.006

Christian, C., D. Ainley, M. Bailey, P. Dayton, J. Hocevar, M. LeVine, J. Nikoloyuk, C. Nouvian, et al., 2013. A review of formal objections to marine stewardship council fisheries certifications. Biological Conservation 161: 10-17.

Drinkwater, K. F., Godø, O. R., Hobday, A. J., Hollowed, A. B., Kristiansen, T., Murphy, E. J.,
Ressler, P. H.,2014. Krill, Climate, Contrasts ICESJMS FSU002 28- Mar-2014. ICES Journal of Marine Science, March, 23.

Garibotti IA, Vernet $M$, Ferrario ME, Smith RC, Ross RM, Quetin L.B., 2003. Phytoplankton spatial distribution pat- terns along the western Antarctic Peninsula (Southern Ocean). Mar Ecol Prog Ser 261: 21-39.

Hernández-León S., Montero I., Almeida C., Portillo-Hahnefeld A., Bruce-Lauli E., 2008. Mesozooplankton biomass and indices of grazing and metabolic activity in Antarctic waters. Polar Biol 31: 1373-1382.

Herr, H., S. Viquerat, V. Siegel, K.-H. Kock, B. Dorschel, W.G.C. Huneke, A. Bracher, M. Schröder, et al., 2016. Horizontal niche partitioning of humpback and fin whales around the West Antarctic Peninsula: Evidence from a concurrent whale and krill survey. Polar Biology 39: 799-818.

Hewitt, R. P., Linen Low, E. H., 2000. The Fishery on Antarctic Krill: Defining an Ecosystem Approach to Management. Reviews in Fisheries Science, 8(3), 235-298.

Hill, S. L., Atkinson, A., Pakhomov, E. A., Siegel, V., 2019. Evidence for a decline in the population density of Antarctic krill Euphausia superba. Journal of Crustacean Biology, 39(3), 316-322.

Hinke, J. T., Cossio, A. M., Goebel, M. E., Reiss, C. S., Trivelpiece, W. Z., Watters, G. M., 2017. Identifying Risk: Concurrent overlap of the antarctic krill fishery with krill-dependent predators in the scotia sea. PLoS ONE, 12(1).

Ichii, T., 2000. Krill harvesting, [w:] I. Everson (red.) Krill: Biology, Ecology and Fisheries, Fish Aquat. Resour. Ser., vol. 6, 228-262, Blackwell Science, Oxford.

Kawaguchi, S., Ishida A., King R., Raymond B., Waller N., Constable A., Nicol S., Wakita M., Ishimatsu A., 2013. Risk maps for Antarctic krill under projected Southern Ocean acidification, Nat. Clim. Change, 3, 843-847. 
Kawaguchi, S., Nicol, S., Press, A. J., 2009. Direct effects of climate change on the Antarctic krill fishery. Fisheries Management and Ecology, 16(5), 424-427.

Krüger, L., Huerta, M. F., Santa Cruz, F., Cárdenas, C. A., 2020. Antarctic krill fishery effects over penguin populations under adverse climate conditions: Implications for the management of fishing practices. Ambio, August.

Lehette, P., Tovar-Sánchez, A., Duarte, C. M., Hernández-León, S., 2012. Krill excretion and its effect on primary production. Marine Ecology Progress Series, 459, 29-38.

Mcbride, M. M., Dalpadado, P., Drinkwater, K. F., Godø, O. R., Hobday, A. J., Hollowed, A. B., Kristiansen, T., Murphy, E. J., Ressler, P. H., Subbey, S., Hofmann, E. E., Loeng, H., 2014. Krill, Climate, and Contrasting Future Scenarios for Arctic and Antarctic Fisheries. ICES Journal of Marine Science, 71(7), 1934-1955.

Medley, P., G. Pilling, A. Payne, A. Hough, Davies S., 2009. Antarctic krill pelagic trawl fishery certification. 82083/Moody Marine/Public Certification Report

Miller, A.K., Kappes M.A., Trivelpiece S.G., Trivelpiece W.Z., 2010. Foraging-niche separation of breeding gentoo and chin- strap penguins, south shetland islands, Antarctica. The Condor 112: 683-695.

Nash, S. M. B., Schlabach, M., Nichols, P. D., 2014. A Nutritional-toxicological assessment of antarctic krill oil versus fish oil dietary supplements. Nutrients, 6(9), 3382-3402.

Nicol, S., 2006. Krill, currents, and sea ice: Euphausia superba and its changing environment. BioScience, 56(2), 111-120.

Nicol, S., Endo, Y., 1999. Krill fisheries: Development, management and ecosystem implications. Aquatic Living Resources, 12(2), 105-120.

Nicol, S., Foster, J., 2003. Recent trends in the fishery for Antarctic krill. Aquatic Living Resources, 16(1), 42-45.

Ommaney F. D., 1938. South Latitude: Below the Roaring Forties. New York: Longmans.
Piñones, A., Fedorov, A. V., 2016. Projected changes of Antarctic krill habitat by the end of the 21st century. Geophysical Research Letters, 43(16), 8580-8589.

Prado-Cabrero, A., Nolan, J. M., 2021. Omega-3 nutraceuticals, climate change and threats to the environment: The cases of Antarctic krill and Calanus finmarchicus. Ambio 50, 1184-1199

Santa Cruz, F., Ernst, B., Arata, J. A., Parada, C., 2018. Spatial and temporal dynamics of the Antarctic krill fishery in fishing hotspots in the Bransfield Strait and South Shetland Islands. Fisheries Research, 208, 157-166.

SC-CAMLR. Report of the Sixteenth Meeting of the Scientific Committee (SC-CAMLR-XVI). CCAMLR, Hobart, Australia (1997).

Schmidt, K., Atkinson, A., Steigenberger, S., Fielding, S., Lindsay, M. C. M., Pond, D. W., Tarling, G. A., et al., 2011. Seabed foraging by Antarctic krill: implications for stock assessment, bentho-pelagic coupling, and the vertical transfer of iron. Limnology and Oceanography, 56: 14111428.

Soevik, T., Braekkan, O., 1979. Fluoride in Antarctic Krill (Euphausia superba) and Atlantic Krill (Meganyctiphanes norvegica). Journal of the Fisheries Board of Canada, 36(11), 1414-1416.

Storebakken, T., 1988. Krill as a potential feed source for salmonids. Aquaculture, 70(3), 193-205.

Teschke, K., Pehlke, H., Deininger, R., Jerosch, K. (2016). WG-EMM. June.

Ulven, S. M., Holven, K. B., 2015. Comparison of bioavailability of krill oil versus fish oil and health effect. Vascular health and risk management, 11, 511-524.

Varela M, Fernández E, Serret P., 2002. Size-fractionated phytoplankton biomass and primary production in the Gearlache and south Bransfield Straits (Antarctic Peninsula) in the austral summer 1995-1996. Deep-Sea Res // 49: 749-768.

Zhang, H.Y., Cao, M.X., Fodjo, E. K., Kong, C., Cai, Y.Q., Shen, X.S., Chen, X.Z., 2019. Safety 
of Antarctic krill (Euphausia superba) as food source: its initial fluoride toxicity study. Food Science and Technology, 39(4), 905-911.

\section{Źródła internetowe:}

[1] www.ccamlr.org/en/fisheries/krill-fisheriesand-sustainability

[2] http://ocean71.com/chapters/krill-antarcticfishing-tiny-crustacean-change-world/

[3] fish-

docs.ccamlr.org/FishRep_48_KRI_2020.ht ml\#2_Reported_catch

[4] https://www.akerbiomarine.com/

[5] https://www.asoc.org/advocacy/krill-conservation

[6] https://www.superbakrill.com

[7] https://www.rimfrostkrill.com/krill-nutrients\#marine-omega3

[8] https://www.webmd.com/vitamins/ai/ingredientmono-1172/krill-oil

[9] https://www.aquaculturealliance.org/advocate/will-krill-fulfill-its-promise-as-anaquaculture-feed-ingredient/

[10] https://www.qrillaqua.com/salmon-healthwith-krill
Notka o autorce: Pani Kinga Hoszek jest studentką I roku MSU na kierunku Oceanografia. Jej wielką pasją są podróże, ale przede wszystkim morza i oceany - badania, jak również ochrona. 